\title{
Research Libraries of Scandinavia
}

Mr. Rod is librarian, Augustana College, Rock Island, Ill.

$\mathrm{D}$ URING THE SPRING and summer of 1947 it was my good fortune to spend about three months in Denmark, Finland, Norway and Sweden as a fellow of the International Relations Board of the American Library Association. The primary purpose of the stay was to gather data for a doctoral dissertation at the University of Chicago Graduate Library School, dealing with the subject of American publications in the research libraries of Scandinavia. Most of the large and more important scholarly libraries were visited, and particularly those which were concerned with the humanities and social sciences, since the study was confined to four subjects in the latter area. This article will include none of the materials or findings relating directly to the thesis itself, but will merely record some rather general impressions and observations of Scandinavian libraries and librarianship.

Four of the most important libraries of Sweden are the Royal Library in Stockholm, the university collections at Uppsala and Lund, and the Gothenburg Stadsbibliotek, all supported by the national government. Each is a copyright depository, and receives one copy of every Swedish publication. A rather burdensome obligation which goes with this designation is that of preserving complete files of all newspapers published in the country. Legal considerations make impossible the more reasonable course of placing on any one library responsibility for only a share of the I3 provinces.
The library at Uppsala is the largest, numbering well over one million volumes, and is, in some respects, the finest of the four. Its reference and research materials are outstanding, and a thesis collection alone contains over 500,000 items. This institution, now under the direction of Dr. Tonnes Kleberg, has had worldwide exchange relations since the eighteenth century, and a considerable part of its rich collections has been acquired through these contacts.

While in Sweden, I spent more time at the Royal Library in Stockholm than anywhere else, and consequently became quite well acquainted with several members of the staff. Now under the direction of Dr. O. Wiselgren, the library was for many years headed by Dr. Isak Collijn, long associated with international library affairs. The library, located in a small park just off one of the main business centers of the city, concerns itself primarily with Swedish and Swedish-American materials, and the humanities. It is the national library and is the center of scholarly library activity in the country; two members of the staff devote their time to the compilation of an annual published catalog of foreign acquisitions which lists additions of such materials in all Swedish research institutions.

The staff accorded me every assistance, and evidenced not only a professional interest in a fellow librarian from the U.S., but also a genuine personal friendship. Particularly thoughtful and helpful was Dr. Gösta Ottervik, who was described to me several times as "the hardest working librarian in Sweden." The following is 
given, not to embarrass Dr. Ottervik, but to describe one who typifies the best among Scandinavian research library personnel. Besides functioning full time in the foreign acquisitions department, he compiles for the publishing trade its annual catalog of Swedish publications, and also is editing the much more complete and pretentious five-year index for the same group. Last year he was in Paris for some months to take charge of the Scandinavian collection at the St. Genevieve Library. In addition to his native Swedish, he speaks French, German, and English, and wrote his doctoral dissertation on some aspect of Greek philology. But lest you think such scholarly attainments may have extinguished every spark of the human in him, let me assure you that he has a charming sense of humor, makes good talk, and is an accomplished musician and gracious host.

Considerably less time was spent at the University of Lund and the Gothenburg Stadsbibliotek. The Lund collection, while not as large or as rich as that of its sister and rival institution at Uppsala, is a university research library of real stature. The Gothenburg library limits itself pretty much to the humanities; it is the only one of the four libraries which has a pressing need for new quarters, and plans for a new edifice are in the making.

\section{Oslo}

The library which gave evidence of the American and British influence upon it more than any other which I saw in Scandinavia was that of the University of Oslo in Norway, whose director is Wilhelm Munthe, well known in this country primarily because of his volume American $\mathrm{Li}$ brarianship from a European Angle. The Oslo collection, just as the University of Helsinki Library in Finland, serves also as the national library, these two institutions being rather unusual in this respect. The library is the legal depository for Norwegian publications, and its budget is set up separately from that of the university. With well over one million volumes, the collection is by far the largest in Norway. A highly competent staff is organized along the lines of British and American practice; of a total of 80 , about 30 are professional, with a director and four department heads. The public catalog room contains an excellent card index, both author and subject, and also houses a good collection of printed bibliographies. A professional staff member is available for consultation during the busiest hours.

The building itself is a very impressive and modern structure, with two large wings extending back from the original unit constructed in 1914. One of the wings was constructed partly during the recent occupation, and was completed only after the cessation of hostilities. There are public reading rooms, comfortable and well lighted, with seating facilities for over 300 persons. Workrooms are roomy and well planned, and the staff quarters, with its roof terrace overlooking the harbor, has given many a visitor a twinge of envy. The building is located some blocks from the university campus, but this inconvenience to students is alleviated somewhat by the provision of cloak and locker rooms, and an adjacent cafeteria with an open terrace. The university is being relocated on a new campus at the edge of the city, and in the event of the completion of that project, it is conceivable that the present dual function of the library will be separated into a purely university collection on the new site with a national library continuing in the present building.

\section{Finland}

One of the highlights of the trip was the 
week spent in Finland, two days at the port city of Turku on the west coast, and five days in the capital city of Helsinki. Companions on the overnight Baltic boat crossing from Stockholm were the chief library advisor of the Swedish Board of Education, Bengt Hjelmqvist, and his wife.

To walk down the gangplank of a ship which has just brought one to a completely foreign country 5000 miles from home and hear oneself paged is a sensation that defies description. Dr. L. O. Th. Tudeer, chief of the university library in Helsinki whom I had met the week previously at the conference of the International Federation of Library Associations in Oslo, was unable to meet me at the boat, and so had arranged to have a colleague see that I was properly escorted to the sessions of the Finnish $\mathrm{Li}$ brary Association meeting which I had come to attend. From the very first I was aware of a very real friendliness on the part of my hosts, and it was with a feeling of nothing but admiration and affection for Finland and the Finnish people that I left the country a week later.

The sessions of the library meeting were conducted in Finnish, and so the speeches and discussions were quite unintelligible to me. But there seemed to be lively interest in the topics considered, and a goodly number of individuals contributed. In many respects the conference resembled a state meeting in this country. There were about 350 librarians in attendance.

There are two institutions of higher learning in Turku, the Finnish University and the Swedish Academy. It should be explained that about io per cent of the country's population is of Swedish stock, and that this element has been jealous of its culture to the point of preserving the language and maintaining its own schools. Among the educated classes in the country, both the Finnish and Swedish tongues are spoken, and such things as cities and streets always are given names in both languages. The Swedish Academy has the first unit of a new and modernistic building, and has an excellent Swedish collection built up by its scholarly and energetic chief, Dr. Eric Holmberg. The other library is in very cramped quarters, with some of the staff even having to work at desks in the stack aisles. A new building is planned, though there is no assurance as to when such plans can be carried forward.

The university library in Helsinki, the most important in Finland, is a striking example of what an institution can become and do in spite of the handicap of desperately inadequate building and facilities. The building is old, crowded, and inconvenient almost to despair. Acquisition and cataloging are carried on in a cumbersome room that formerly was an exhibition hall. The librarian's office is hardly more than a desk in an uninviting room that is anything but worthy of the individual holding that important position. Some years ago the book storage facilities were expanded, and radial stacks of solid and inlaid mahogany were installed. But the collection is excellent in many respects, particularly in the completeness of its Finnish materials. Because of the foresight of the administration, as well as the heroism of a couple of the members of the staff during a bombing fire that threatened part of the collection, the library came through the war unscathed. Plans for a new building are ready, but there is little hope that any construction can begin at an early date.

The parliament library, which through a cooperative agreement with the university serves also as the main social science research collection in the country, is located in the magnificent new building of the Finnish Diet. The library has been the recipient of a great deal of material from the 
American Book Center and the Library of Congress; American pùblic documents are in heavy demand by government departments and officials.

\section{Danish Royal Library}

Perhaps the outstanding collection in Scandinavia is the Danish Royal Library in Copenhagen. It is, of course, unusually strong in Scandinavian materials, and its rich manuscript collection, including a renowned body of Icelandica, has attracted scholars the world over. There was a fascination in being able to handle the original manuscripts of such things as Hans Christian Andersen's fairy tales and Soren Kirke'gaard's philosophical writings, as well as some of the earliest copies of the Icelandic sagas. The Royal Library is the national collection of Denmark, and has more than a million volumes. Together with the university library in Copenhagen, it is under the direction of the state librarian, which office was created a few years ago in an effort to coordinate the development of the research collections. The building is a very attractive one, and is one of the better library structures in northern Europe.

With a history of more than 450 years, the university library in Copenhagen is the oldest in the country, but is considerably smaller than the Royal Library. There are really two university collections, the humanities being housed in the old building in the heart of the city, while the sciences, including particularly medicine and physics, are located in one of the finest new library buildings in all of Scandinavia, on the new university campus farther out.

A relatively small collection, numbering only slightly more than 100,000 volumes, but nevertheless one of growing importance, is that of the Danish Technical Library. This institution represents the amalgamation of a number of libraries, the final phases of the union being decided upon in 1938. In 1942 a new building was occupied, and the agreement between the Danish Technical University and Industrial Society put into effect; the library is a state institution, but continues to receive a considerable part of its financial support from private industries which it serves in addition to the technical schools.

Even to begin to record the flood of impressions accumulated during the weeks in Scandinavia is difficult, to say the least. Just as it was surprising to find a few libraries still shelving books from the bottom of a section to the top instead of the usual reverse, it was refreshing to find reading rooms and stacks immaculate, with everything in good order and with no trace of the dust to which research libraries in this country too often find themselves accustomed. Buildings were as varied as one would find anywhere, ranging from such structures as those at Oslo and Copenhagen which had all of the latest innovations and devices to those less fortunate ones which were ancient and inconvenient, with essentially the same equipment they must have had Ioo years ago.

There were instances in which the professional members of staffs seemed to be too much occupied with clerical details and menial tasks that might well have been assigned elsewhere. Much of the page work in some of the libraries was performed by professional librarians, which may be explained in part by the detailed charging system employed in some cases. A charge slip would be filled out in triplicate, with one copy being placed in the files under the class or call number, another under the borrower's name, and a third on the shelves in the spot from which the volume was removed. The result is, of course, an almost perfect record of the status of the book stock, as well as shelves which are the dream of every stack supervisor. 
To understand just how such time consuming procedures are possible, it must be remembered that the pace of activity is much slower than in a typical American university library, for example. In general, much more attention is paid to the painstaking research of the advanced scholar than to the type of activity which characterizes most American institutions of higher learning and their libraries. In some of the libraries, it was not at all unusual to have some professor or other scholar leave a book request one day, and call for the item the following day. Many of the circulation departments closed at three or so in the afternoons although the library might be open until nine or ten o'clock in the evening. Fundamental to an understanding of all this is the realization that European people in general are much more leisurely in all their activities, and are not cursed with our obsession for speed and efficiency.

The Uppsala university collection may well serve to illustrate some of the conditions typical of Scandinavian research libraries. The building has been renovated rather recently and the result is, in many respects, a good library structure. Even here, however, a portion of the building was left in its original state out of deference to tradition, the effect being that the administration has to cope with a structural situation that is galling, to put it mildly. But the building has the best of such modern equipment as book lifts and elevators, pneumatic tube service, steel stacks and good lighting. The main reading room contains an unusually fine reference and research collection; throughout the room are individual study tables, which are assigned much as are our carrels or cubicles and to which students may have books charged for indefinite periods of time. The official catalog is in manuscript, written on sheets of legal size paper, and is kept in boxes in shelves back of the circulation desk; a public card catalog was begun a few years ago, but the administration is well aware of the fact that one of its most pressing problems is to modernize its cata$\log$. As it is, newly acquired titles of an author are simply added to the sheets in order of arrival, with the result that it becomes a burdensome task to run down a particular title of a prolific writer.

Uppsala may serve also to illustrate a typical difference between the function of a Scandinavian university library as contrasted with that of a similar institution in this country. The university library is designed primarily to serve the advanced research student and the faculty, and the undergraduates have little contact with it. Their needs are served by the collections found in the various schools or institutes in which they might be studying, many of these smaller collections being quite independent of the university library. Then, too, there are sizeable libraries to be found in the houses of the various "nations." These "nations" are a combination fraternity and sorority, with all students coming from any one province automatically being members of the "nation" or society for that province. To indicate the importance of this aspect of Swedish student life, one of the houses which I visited had just been redecorated at a cost of 600,000 Swedish crowns, or about $\$ 175,000$. Its library numbered between five and ten thousand volumes. When one considers the library facilities available at a Scandinavian university, this complete picture must be borne in mind.

\section{Personnel}

In the matter of personnel, several differences are immediately apparent. The term "librarian" is used much more specifically and accurately than in this country, with such terms as chief librarian, first li- 
brarian, and the like connoting a definite status which is completely standardized. There are no library schools for the professional training of personnel for the research libraries, and it is in this preparation of librarians that a fundamental difference occurs. The usual educational process is for an individual to obtain the doctorate or some other advanced degree in a subject field, and then to undergo a period of inservice training or apprenticeship in a library. After a specified period of such apprenticeship, a person is given the professional rank and title of "librarian." What library schools there are, usually in the form of a short course conducted by librarians from some of the larger institutions or from the government library department, are concerned primarily with the teaching of personnel either for the public libraries or for what might be considered the subprofessional and clerical positions with the research libraries.

The obvious effect of this type of training is that staffs tend to consist of scholars rather than administrators and technicians. There is a much deeper concern with the contents of books than with the niceties of administration and technique. This scholarship on the part of the professional library staff demonstrates itself not only in the type of service given in the reference departments and at circulation desks, but also in the individual's activities away from the job. I think of the Norwegian librarian whose idea of a vacation recently was to spend a month in Copenhagen poring over seventeenth century manuscripts relating to a history of science which he is writing in his spare time, and of a Danish colleague who has written an excellent monograph on the clandestine literature of the occupation period in Denmark. I was in the homes of a number of librarians, and was amazed at the size and quality of many of their personal libraries, some of them constituting several thousands of volumes. Much as American librarians may excel in certain aspects of library administration, it seemed to me that we suffered rather badly by comparison when the matter of scholarship was injected into the picture.

In the matter of salaries, Scandinavian librarians are as unfortunate as most of their American colleagues. One rather substantial difference, however, is the fact that there is not the same wide range between the highest and lowest professional salaries. For example, a chief librarian might receive fourteen or fifteen thousand crowns per year, while the pay of all other librarains on the staff would fall between ten and thirteen thousand crowns annually. The theory seems to be that the prestige of the various positions is differentiation enough, and that there should not be too great disparity among the salaries.

The careers of librarians are much more circumscribed than is true in this country in that the small number of research libraries, as well as the fact that none are very large, makes the chance of moving from one institution or position to another quite remote. When one has reached the status of first librarian, the probabilities of finding opportunities for advancement either in rank or salary are limited.

\section{Book Trade}

To fail to comment about the book trade would be to slight an outstanding part of the Scandinavian picture. An American traveler could not fail to be impressed with the number and quality of the bookstores, and at times it seemed that one could not stroll along the business sections of any of the cities or towns without encountering at least one such establishment in each block. The healthy state of the second-hand trade (Continued on page 405) 
the college or university librarian in China, with all his training, experience, and interest in the work, can be given a better academic status and a more recognized faculty ranking in the institution which he serves. It is then, and only then, that the ambitious Chinese librarians who have received proper training in the West will not be easily lured to a more tempting field other than the profession in which he was trained. I honestly believe that the profession of college librarianship, in spite of all its shortcomings and low attraction, should be one of the most wholesome and decent professions in China. On the other hand, while we must have enough faith and interest in the work we are doing, we should, at the same time, be given enough respect in the position we hold to keep us from being enticed to other walks of life which may be more lucrative. I agree with a $W$ isconsin librarian, who went to China years ago, that the term "librarian" should not be abused, and I hope that many will be attracted to this young profession in China despite its being a little bit undervalued at present.

\section{Research Libraries of Scandinavia}

\section{(Continued from page 343)}

is especially noticeable. The personnel of the bookstores appeared to be thoroughly acquainted with their wares, and very professional in manner.

One of the finest bookstores visited was the Akademiska Bokhandel in Helsinki, the largest in all of northern Europe. The store sells nothing but books, and employs a staff of over 200. When one considers that Helsinki has a population of hardly more than 300,000 , and that there are literally dozens of bookstores in the city, Akademiska Bokhandel is little less than amazing. The manager of the concern was justly proud of his establishment, which is patronized widely by libraries and individuals throughout Scandinavia, and stated that he could sell many times the present amount of British and American books if he were allotted the necessary pound and dollar exchange with which to import them. The postwar period has seen a sizeable increase in the book trade, inasmuch as people have little else which they are able to buy, and also because of a growing interest in what has happened and is happening throughout the other parts of the world.

There is a great deal of interest in British and American publications in all the Scan- dinavian countries, and the purchase of such English language books by the libraries and bookstores is limited almost solely by the foreign currency exchange made available to them by their respective governments. The manager of one of the better bookstores in Oslo stated that prior to the war his annual sales of American publications, both popular and scholarly, exceeded $\$ 50,000$. At the present time English language items disappear from the shelves almost as rapidly as they are secured for sale, with current government regulations limiting importations almost entirely to scientific fields. Were it not for these necessary restrictions, the postwar scale of books in English would far outdistance the earlier annual figure.

To recall again in writing some of the impressions of 10 weeks among the libraries and librarians of Scandinavia is to kindle nostalgia. It is to be hoped that these few observations will at least have given impetus to a few readers' interest in an area of European librarianship perhaps not so widely known among the profession in this country. To present an authoritative account would require considerably more than an article of this length based upon a visit of such short duration. 